\title{
Estimating Potential Woody Biomass Supply under Sustainable Timber Production from Plantation Forests in a Snowy Mountainous Region of Japan
}

\author{
Satoshi Tatsuhara ${ }^{1 *}$
}

(1) The University of Tokyo, Graduate School of Agricultural and Life Sciences, Department of Forest Science, 1-1-1 Yayoi, Bunkyo-ku, 113-8657 Tokyo, Japan

* Correspondence: e-mail: tatsu@fr.a.u-tokyo.ac.jp

\begin{abstract}
Citation: Tatsuhara S, 2020. Estimating Potential Woody Biomass Supply under Sustainable Timber Production from Plantation Forests in a Snowy Mountainous Region of Japan. South-east Eur for 11 (1): 2939. https://doi.org/10.15177/seefor.20-01 Received: 26 Sep 2019; Revised: 14 Dec 2019; Accepted: 22 Dec 2019; Published online: 26 Feb 2020
\end{abstract}

\begin{abstract}
Numerous woody biomass-powered stations for energy generation have been constructed in Japan since the Feed-in Tariff Scheme was introduced. However, a stable, long-term woody biomass supply from plantation forests is necessary for the construction and operation of such power stations. The logs that are used to produce fuel chips are harvested from roundwood. Thus, the main objective of this study was to estimate the potential supply of woody biomass resources under the condition of maximum sustainable harvesting from privately-owned plantation forests. Another aim was to examine the stability of sustainable harvest volumes from periodical changes. The study focused on privately-owned forests in the Sampoku district of Murakami City in the northernmost part of Niigata Prefecture, Japan. Trees in the studied region are commonly bent during periods of high snowfall, and the current bucking strategy - influenced by the construction of a biomass-powered generation facility - was integrated into the model. The revenues and costs of plantation management and timber production were calculated based on stands' geographical attributes using a geographic information system. A mixed integer programming model was used to predict the maximum sustainable harvest levels that would provide stable profits. The simulation showed that even though the trees had a unimodal age class distribution, sustainable harvest volumes ensured a sustainable supply of woody biomass over various rotation ages. Extending the range of rotation ages by 20 years dramatically increased the potential supply of woody biomass resources. Fluctuations in each woody biomass resources were mostly less than $20 \%$ over the planning horizon. The presented research could be useful to regional forest resource managers and stakeholders involved in biomass-powered energy generation or the purchasing of woody biomass.
\end{abstract}

Keywords: bucking strategy; maximum sustainable harvest; profitability; sustainability; woody biomass-powered station

\section{INTRODUCTION}

A Feed-in Tariff (FIT) Scheme for renewable energy use has been in effect since July 2012 in Japan. This FIT scheme has stabilized the return from investment expected for Japanese renewable energy projects, since the scheme guarantees that the electricity generated from renewable energy sources will be purchased at a fixed price over a long-term period. As a result, the Japanese renewable energy market has rapidly expanded following the entry of companies which were previously not linked to electricity generation (NEDO 2014). The tax exclusive tariffs for electricity generated from woody biomass - that is, biomass from thinning and final cutting in areas covered by 'forest management plans' - are 32 yen $\cdot \mathrm{kWh}^{-1}(0.256$ $€ \cdot \mathrm{kWh}^{-1}$; currency exchange rate: yen/€, January 2020) for facilities with a generation capacity over $2,000 \mathrm{kw}$ and 40 yen.kWh ${ }^{-1}\left(0.32 € \cdot \mathrm{kWh}^{-1}\right)$ for facilities with a generation capacity under $2,000 \mathrm{kw}$. These tariffs are higher than what is provided for other feedstocks, such as sewage residues and building material waste. For this reason, many power stations which use woody biomass as a feedstock have been 
constructed after the induction of the FIT Scheme, which has considerably burdened the supply of woody biomass (Ando 2013). Thus, a stable, long-term supply of woody biomass from plantation forests is necessary for the construction and operation of woody biomass-powered generation facilities.

In the northern part of Niigata Prefecture, Japan, the bucking strategy for felled trees with butts that have been bent by snow cover has changed after one biomass-powered generation facility started to purchase fuel wood chips. In the case of regular roundwood, the top part of felled trees used to become residue after bucking, while bent trees were cut to avoid the bent part of the tree. More specifically, the butt log used to be cut about $1 \mathrm{~m}$ above ground level to obtain the best possible log. In the current situation, which includes a buyer of fuel wood chips, small-diameter logs are cut from the top part of the felled tree. When bucking bent trees, a 2-meter-long butt log is cut from the regular stump height (this includes the bent part, which can be used to produce fuel wood chips). The logs that will be used to produce wood chips are harvested from roundwood because the profitability of plantation forest management in Japan is generally low and, as such, it makes sense from an economic perspective to utilize as much of a felled tree for value-added products as possible.

Researchers have previously attempted to estimate the potential supply of woody biomass by using geographic information system (GIS) data and forest growth models. Nord-Larsen and Talbot (2004) estimated economically feasible annual fuel wood resources in Denmark by applying a model that optimized allocation and transportation costs. Ranta (2005) applied a similar approach by creating a model that used availability comparisons between power generation facilities and resource allocation to estimate the technically and economically viable supplies of biomass from final cuttings in Finland. Yamaguchi et al. (2014) estimated the annual supply of timber and logging residues at a regional scale in Japan based on known cutting and extraction rates. In another Japanese study, Aruga et al. (2014) calculated the potential annual economic supply of forest biomass resources at a regional level under a rotation age of 60 years. Moreover, the potential supply of woody biomass was estimated by incorporating the long-term harvesting schedules of plantation forests. Aruga et al. (2006) investigated the potential of timber and logging residue volumes in a specific Japanese county by applying a random search technique to a model that included a harvesting cost constraint. In a Norwegian study, Rørstad et al. (2010) used linear programming that maximized profitability under non-declining harvest constraints to estimate the supply of harvest residues' supply at a regional scale. However, the sustainable supply of woody biomass, i.e. the supply that will remain stable over a long-term period, in Japan has not yet been clarified.

The presented research aimed to estimate the potential supply of woody biomass in a specific district under the condition of maximum sustainable harvest of timber from plantation forests, as well as to determine how changes in the rotation age would influence this supply. An additional objective was to clarify how resistant the supply is to changes by the ten-year planning period, since the district under study is located in a snowy mountainous region of
Japan. Bucking was simulated based on the current strategy in the district under study. The focal district includes plantation forests with unimodal age class distributions. However, it is important to note that some of the plantation forests are not suitable for profitable timber production. Furthermore, sustainable harvest levels cannot be easily predicted based on the growing stock, and its growth, in the district. In this research, sustainable harvest was defined as the stable production and profits over a planning horizon. The geographical attributes of stands were used to calculate the revenues and costs that are relevant to decisions regarding final cutting age. The supply of biomass resources was then predicted for several scenarios based on maximum sustainable harvest levels.

\section{MATERIALS AND METHODS}

\section{Study Area}

The study focused on numerous small-scale, privatelyowned forests in the Sampoku district of Murakami City in the northernmost part of Niigata Prefecture, Japan (Figure 1). The district is one of the prefecture's most active forestry regions. The studied forests included 13,792 sugi (Cryptomeria japonica D. Don) stands covering at least 0.1 ha, representing an area of 8,701.5 ha. A clear majority $(86 \%)$ of these sugi plantations are covered by the 'forest management plans' from 2015. The stands currently show a unimodal age class distribution, which is a common characteristic of Japanese plantation forests (Figure 2). Timber production in Sampoku district amounts to $15,000-20,000 \mathrm{~m}^{3}$.year ${ }^{-1}$. The Northern Niigata Wood Processing Cooperative produces sawn and laminated wood from domestic medium-diameter logs, and has a log processing capacity of $24,000 \mathrm{~m}^{3}$.year ${ }^{-1}$. Niigata Prefecture Forest Owners' Co-operative Association mediates arranged transactions of logs - with agreed volumes at fixed prices between log producers and customers such as the Northern Niigata Wood Processing Cooperative, sawmills, plywood manufacturers, and suppliers of fuel wood chips to a woody biomass-powered facility in Niigata City with a generation capacity of 5,700 kW. The regeneration treatments and prescribed silvicultural regimes (hereinafter prescriptions) applied in the sugi plantations are summarized in Tables 1 and 2 , respectively.

\section{Data}

The presented research used forest GIS data provided by the Niigata prefectural government, while contour and elevation point data were provided by the Geospatial Information Authority of Japan (2012), and road data were digitized from 1:5,000 scale forest maps (Tatsuhara and Dobashi 2006). The research is also based on information from interviews with representatives of the forest owners' cooperative in Murakami City about the current status of forests and silvicultural operations in the study site. Information about the current subsidies provided in the prefecture was obtained from the Niigata prefectural government, while the relevant quality standards and prices for logs were obtained from the Niigata timber market and interviews with customers of sugi logs. 


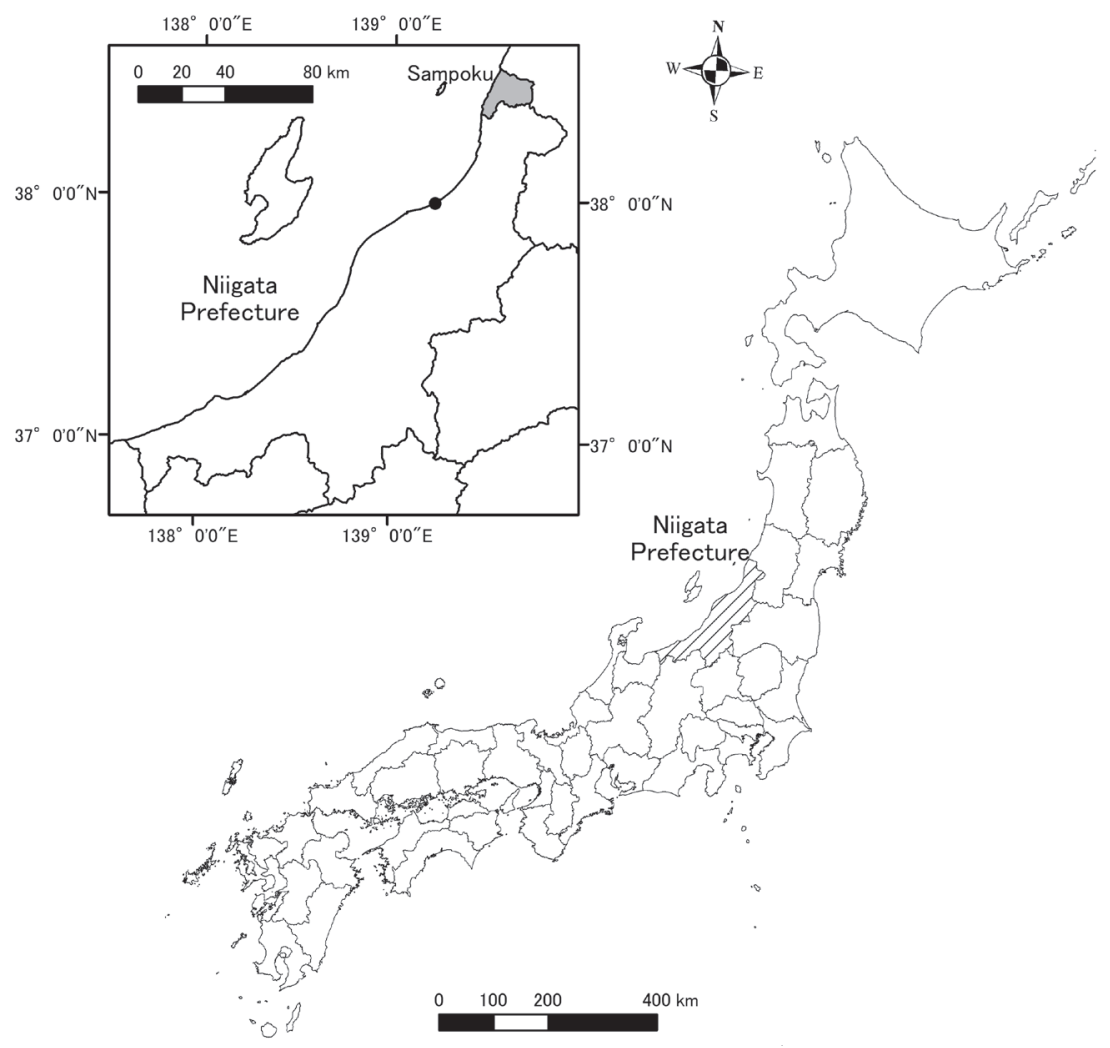

Figure 1. Study site. Black circle depicts the location of a woody biomass-powered station which purchases logs.

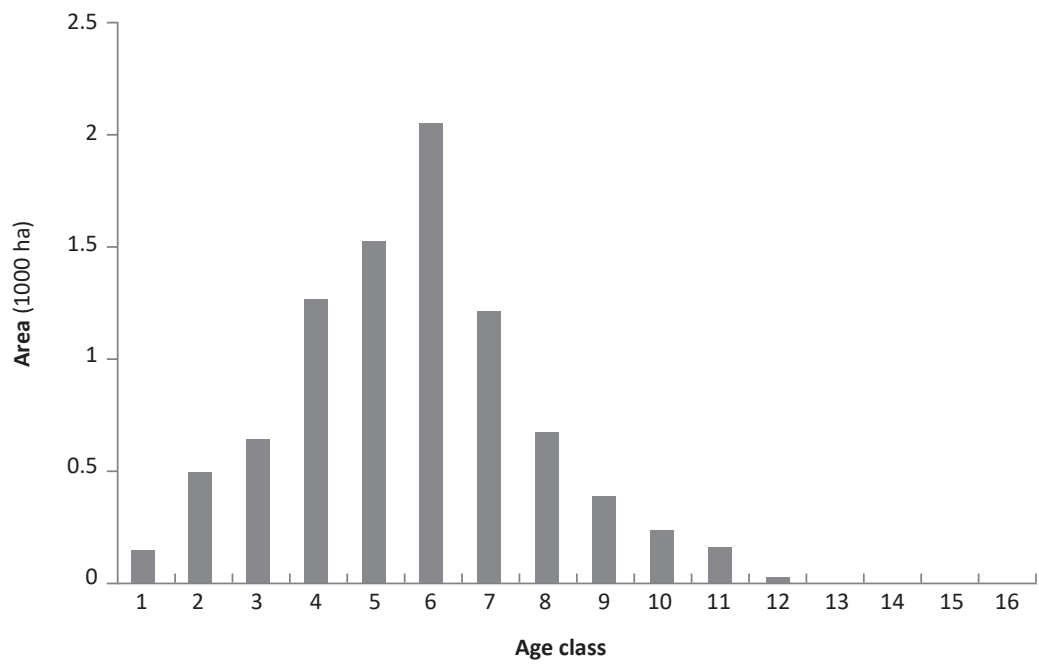

Figure 2. Age class distribution, in 10-year classes, of the studied stands at the beginning of the planning horizon. 


\section{Predicting Yield and Calculating Profit}

Yields and profits were calculated for stands under each prescription according to the methodology presented by Moriya and Tatsuhara $(2014,2017)$, as summarized below. ArcGIS 10.3 (Esri, Redlands, CA, USA) was used as the GIS software to obtain spatial information.

The average heights of dominant and codominant trees in each stand were calculated from stand age and site class entries in the forest inventory data according to height/age curves published by the Niigata Prefectural Government (1980). The yield from each stand, which took into consideration the applied prescription, was predicted using the stand density control diagram for sugi plantations along the Sea of Japan in the Tohoku and Hokuriku regions published by the Forestry Agency of Japan (1981). The height of trees in each diameter class was estimated using

Table 1. Regeneration treatments and the corresponding person-day (person-day ha $^{-1}$ ) requirements.

\begin{tabular}{|c|c|c|c|}
\hline \multirow{2}{*}{$\begin{array}{c}\text { Stand age } \\
\text { (year) }\end{array}$} & \multirow{2}{*}{ Treatment } & \multicolumn{2}{|c|}{ Site class } \\
\hline & & 1 and 2 & 3 and 4 \\
\hline \multirow{2}{*}{1} & Land preparation & 26.68 & 26.68 \\
\hline & Planting & 20.25 & 20.25 \\
\hline 2 & Weeding & 8.85 & 8.85 \\
\hline 3 & Weeding & 8.85 & 8.85 \\
\hline 4 & Weeding & 8.85 & 8.85 \\
\hline 5 & Weeding & 8.85 & 8.85 \\
\hline 6 & Weeding & 8.85 & 8.85 \\
\hline 7 & Weeding & - & 8.85 \\
\hline 12 & $\begin{array}{l}\text { Pre-commercial } \\
\text { thinning }\end{array}$ & 16.24 & 16.24 \\
\hline 15 & $\begin{array}{l}\text { Pre-commercial } \\
\text { thinning }\end{array}$ & 16.24 & 16.24 \\
\hline 20 & $\begin{array}{c}\text { Pre-commercial } \\
\text { thinning }\end{array}$ & 16.24 & 16.24 \\
\hline
\end{tabular}

Person-davs obtained from Tovama et al. (2009) a previously presented height-diameter curve (Nagumo et al. 1981). The stem form of trees in each diameter class was estimated using the following formula, with the values of certain parameters based on the stand density control diagram:

$$
y^{2}=p x^{r}
$$

where $p$ and $r$ are parameters describing size and form, respectively (Prodan 1965). The simulations included a specific bucking strategy to predict the number and volume of logs that would be obtained from stands under each prescription. More specifically, the 2-meter-long butt log was cut from regular stump height. Then, as many four-meter large-diameter logs with a minimum top-end diameter of $30 \mathrm{~cm}$ as possible were cut from each harvested tree at $10 \mathrm{~cm}$ intervals. When no more large-diameter logs could be cut, the process was next repeated for fourmeter medium-diameter logs (minimum top-end diameter of $16 \mathrm{~cm}$ ), and then for two-meter small-diameter logs (minimum top-end diameter of $6 \mathrm{~cm}$ ). A third of the largeand medium-diameter logs were assumed to be of A-grade (with the remaining two-thirds of B-grade), while all of the small-diameter logs were treated as C-grade.

Eight prescriptions were applied in the simulations, more specifically, seven of the prescriptions were variants of clearcutting systems with rotation ages between 60 and 120 years, while one prescription represented a non-clearcutting system without any operations (Table 2). All of the thinning

Table 2. Assumed prescriptions, from Moriya and Tatsuhara (2017).

\begin{tabular}{ccc}
\hline Prescription No. & $\begin{array}{c}\text { Rotation age } \\
\text { (year) }\end{array}$ & $\begin{array}{c}\text { Thinning ages } \\
\text { (year) }\end{array}$ \\
\hline 1 & 60 & 20,40 \\
2 & 70 & 20,40 \\
3 & 80 & $20,40,70$ \\
4 & 90 & $20,40,70$ \\
5 & 100 & $20,40,70$ \\
6 & 110 & $20,40,70$ \\
7 & 120 & $20,40,70$ \\
8 & \multicolumn{2}{c}{ No operations } \\
\hline
\end{tabular}

Table 3. Assumed bucking priority and log prices (currency exchange rate: yen/€, January 2020).

\begin{tabular}{|c|c|c|c|c|c|}
\hline Order of priority & $\begin{array}{l}\text { Log length } \\
(\mathrm{m})\end{array}$ & $\begin{array}{l}\text { Top end diameter } \\
(\mathrm{cm})\end{array}$ & Grade & Customer & Price \\
\hline $\begin{array}{c}1 \\
\text { (Butt log only) }\end{array}$ & 2.0 & & C & $\begin{array}{l}\text { Supplier of fuel wood chips to a } \\
\text { biomass-powered station }\end{array}$ & $\begin{array}{l}4,572 \text { yen } \cdot t^{-1} \\
\left(36.576 € \cdot t^{-1}\right)\end{array}$ \\
\hline \multirow[b]{2}{*}{2} & \multirow[b]{2}{*}{4.0} & \multirow[b]{2}{*}{$30+$} & A & Niigata timber market & $\begin{array}{l}18,000 \text { yen } \cdot m^{-3} \\
\quad\left(144 € \cdot t^{-1}\right)\end{array}$ \\
\hline & & & B & Plywood manufacturer & $\begin{array}{c}\text { 8,800 yen } \cdot \mathrm{m}^{-3} \\
\left(70.4 € \cdot \mathrm{t}^{-1}\right)\end{array}$ \\
\hline \multirow{2}{*}{3} & \multirow{2}{*}{4.0} & \multirow{2}{*}{$16-28$} & A & $\begin{array}{l}\text { Sawmill and laminated wood } \\
\text { manufacturing complex }\end{array}$ & $\begin{array}{l}\text { 10,500 yen } \cdot \mathrm{m}^{-3} \\
\left(84 € \cdot \mathrm{t}^{-1}\right)\end{array}$ \\
\hline & & & B & Plywood manufacturer & $\begin{array}{c}8,600 \text { yen } \cdot m^{-3} \\
\left(68.8 € \cdot t^{-1}\right)\end{array}$ \\
\hline 4 & 2.0 & $6+$ & C & $\begin{array}{l}\text { Supplier of fuel wood chips to a } \\
\text { biomass-powered station }\end{array}$ & $\begin{array}{l}\text { 4,572 yen } \cdot \mathrm{t}^{-1 *} \\
\left(36.576 € \cdot \mathrm{t}^{-1}\right)\end{array}$ \\
\hline
\end{tabular}

\footnotetext{
* Transportation cost is subtracted.
} 
prescriptions were assumed to be low thinning in which the thinning ratio was $40 \%$ in terms of stem numbers. The number and volume of logs of each length and top diameter class for stands under each prescription were predicted for both final cutting and thinning harvests.

The revenue from the sale of logs was estimated based on the predicted log production and log prices. Log prices were set at the median of the daily middle prices on the timber market and purchase prices of main customers (Table 3). Logs for fuel wood chips are traded at landings as well as at the power station. These prices were averaged and weighted for the current trading amounts, after considering transportation cost to the power station. The green wood density of sugi was set as $0.81 \mathrm{t} \cdot \mathrm{m}^{-3}$, while the moisture content was $130 \%$. Subsidies for regeneration treatments from Niigata prefectural government were considered when calculating profits.

The cost of managing the stands was estimated by summing the regeneration and logging (thinning and final cutting) costs. The estimations assumed that the logging system for both final cutting and commercial thinning includes felling and limbing with a chain saw, full tree cable yarding, and bucking with a chainsaw at landings on forest roads. In each simulation, the thinning operation was specified as either commercial or thinning-to-waste based on the potential profitability of commercial thinning, i.e. sales revenue minus the cost of commercial thinning plus the subsidy provided by the prefectural government for commercial thinning. The area, initial age, and site class of stands were obtained from the inventory data, while slope and distance to a road were calculated using GIS. Maximum and average yarding distances were also calculated in GIS by measuring the distance from each $10 \mathrm{~m} \times 10 \mathrm{~m}$ cell to the road, and then obtaining the maximum and average distances for cells in each stand. The regeneration cost was based on the person-days required for the treatment, which are listed in Toyama et al. (2009) according to stand slope and distance to road (Takahashi et al. 1996). The logging cost was estimated by summing the felling, bucking, yarding, and log transportation costs (Suzuki and Tatsuhara 2016).

The profit over a rotation period for stands under each prescription was calculated based on the corresponding revenue, subsidy and cost estimates. Only prescriptions with a rotation age that did not exceed the initial age and that yielded positive annual profit per ha were considered as possible prescriptions for individual stands. These prescriptions were treated as candidate prescriptions in which they could be assigned to the stand in harvest scheduling.

\section{Predicting Production of Woody Biomass Resources}

Harvesting over the planning horizon was simulated according to four scenarios presented by Moriya and Tatsuhara (2014), namely:

- Scenario 1a, maximizing sustainable level of total harvest volume with a rotation age range of 6-10 age class or 60-100 years;

- Scenario $1 \mathrm{~b}$, maximizing sustainable level of total harvest volume with a rotation age range of 6-12 age class or 60-120 years;
- Scenario 2a, maximizing sustainable level of mediumdiameter log harvest volume with a rotation age range of 6-10 age class or 60-100 years;

- Scenario 2b, maximizing sustainable level of mediumdiameter log harvest volume with a rotation age range of 6-12 age class or 60-120 years.

The 'sustainable levels' indicate the middle of the maximum and minimum of periodic harvest volumes over a planning horizon. Scenarios $1 \mathrm{a}$ and $1 \mathrm{~b}$ aimed for sustainable general timber production, whereas Scenarios $2 a$ and $2 b$ aimed for sustainable timber production based on the type of wood sold to the Northern Niigata Wood Processing Cooperative (medium-diameter logs). Scenarios $1 \mathrm{a}$ and $2 \mathrm{a}$ reflected the current rotation age range, while Scenarios $1 \mathrm{~b}$ and $2 \mathrm{~b}$ expanded the current rotation age range by 20 years.

The following harvest scheduling model was formulated using mixed integer programming (Greenberg 1971). Both the length of a planning period and width of an age class were set at 10 years, and the length of the planning horizon was set at 150 years (15 planning periods). The predicted volumes, revenues and profits could only fluctuate by up to $\pm 10 \%$ over the 150 -year planning horizon, which reflects the threshold for deviation applied by Nelson et al. (1991) and Suzuki et al. (2018) in previous simulations of harvesting and net revenue.

$$
\text { Maximize } \mathrm{z}=V
$$

subject to

$$
\begin{gathered}
\sum_{i=1}^{I} \sum_{j=1}^{J} v_{i, j, t} x_{i, j} \geq(1-r) V \forall t \in\{1, \cdots, T\} \\
\sum_{i=1}^{I} \sum_{j=1}^{J} v_{i, j, t} x_{i, j} \leq(1+r) V \forall t \in\{1, \cdots, T\} \\
\sum_{i=1}^{I} \sum_{j=1}^{J} p_{i, j, t} x_{i, j} \geq(1-r) P \forall t \in\{1, \cdots, T\} \\
\sum_{i=1}^{I} \sum_{j=1}^{J} p_{i, j, t} x_{i, j} \leq(1+r) P \forall t \in\{1, \cdots, T\} \\
\sum_{i=1}^{I} S 0_{i} \leq \sum_{i=1}^{I} \sum_{j=1}^{J} S T_{i, j} x_{i, j} \\
\sum_{j=1}^{J} x_{i, j}=1 \forall i \\
y_{i, j} \geq x_{i, j} \forall i, j \\
x_{i, j}, y_{i, j} \in\{0,1\} \forall i, j
\end{gathered}
$$

where $z$ is the objective function, $V$ is the sustainable harvest volume level during the planning horizon, $\mathrm{P}$ is the profit level during the planning horizon, I is the number of stands $(1,372), \mathrm{J}$ is the number of alternative prescriptions (8), $\mathrm{T}$ is the number of planning periods $(15), x_{i, j}$ is 1 when stand $i$ is assigned to prescription $\mathrm{j}$, and otherwise $0, \mathrm{v}_{\mathrm{i}, \mathrm{j}, \mathrm{t}}$ is the harvest 
volume in the $t$-th planning period when stand $i$ is assigned to prescription $\mathrm{j}, \mathrm{p}_{\mathrm{i}, \mathrm{j}, \mathrm{t}}$ is the profit in the t-th planning period when stand $i$ is assigned to prescription $\mathrm{j}_{\mathrm{i}} \mathrm{SO}_{\mathrm{i}}$ is the stand volume of stand $i$ at the beginning of the planning horizon, $\mathrm{ST}_{\mathrm{i}, \mathrm{j}}$ is the stand volume of stand $\mathrm{i}$ at the end of the planning horizon when stand $i$ is assigned to prescription $j, r$ is the threshold for deviation in the periodic harvest volume and periodic profit $(0.1), y_{i, j}$ is 1 when prescription $\mathrm{j}$ is a candidate for stand $i$, and otherwise 0 .

Equations (3)-(4) and (5)-(6) include even-flow constraints for harvesting and profit, respectively, while Equation (7) includes a non-declining constraint for growing stock. Equations (8), (9), and (10) include constraints for the assignment of a single prescription, possible prescriptions, and binary integers, respectively. The model was solved using IBM ILOG CPLEX Optimization Studio V12.5.1 (IBM, Armonk, NY, USA) on a personal computer. Approximate solutions were obtained by applying the branch-and-cut method with a relative gap tolerance of $0.5 \%$.

The estimations found that $40 \%$ of the A-grade log volume comprised sawing residues. Total woody biomass resources encompassed sawing residues along with the harvested small-diameter logs and butt logs. The sustainability of woody biomass supply was tested by calculating fluctuations in small-diameter log volumes, butt log volumes, sawing residues, and total woody biomass resources as follows:

$$
\begin{aligned}
f & =(\max -(\max +\min ) / 2) /((\max +\min ) / 2) \\
& =(\max -\min ) /(\max +\min )
\end{aligned}
$$

where $f$ is fluctuation, $\max$ is the maximum value over the planning horizon, and min is the minimum value over the planning horizon.

\section{RESULTS}

\section{Harvest Levels}

Scenarios $1 \mathrm{a}$ and $1 \mathrm{~b}$ produced total harvest levels of 245.8 thousand $\mathrm{m}^{3} \cdot$ decade $^{-1}$ and 467.4 thousand $\mathrm{m}^{3} \cdot$ decade $^{-1}$, respectively, whereas Scenarios $2 \mathrm{a}$ and $2 \mathrm{~b}$ yielded medium-diameter log harvest levels of 32.3 thousand $\mathrm{m}^{3}$.decade ${ }^{-1}$ and 71.2 thousand $\mathrm{m}^{3} \cdot$ decade $^{-1}$, respectively. Both the levels of total harvest (Scenarios 1a and $1 \mathrm{~b}$ ) and the levels of medium-diameter log harvest (Scenarios $2 \mathrm{a}$ and $2 \mathrm{~b}$ ) volume increased approximately two-fold when the maximum rotation age grew by 20 years.
Scenario $1 \mathrm{a}$

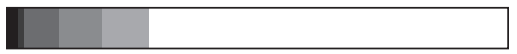

Scenario $1 b$

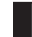

Scenario $2 a$

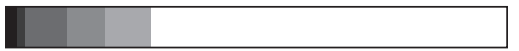

Scenario $2 b$

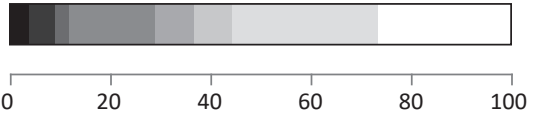

(\%)

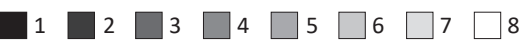

Figure 3. Proportions of the total area of stands assigned to each prescription.

The predicted harvest volumes of total logs and woody biomass resources also increased about two-fold when the maximum rotation age grew by 20 years. However, the growth in volume differed among the various classes of logs. For example, the volume of C-grade logs, especially small-diameter logs, increased less than the volume of total logs when the rotation age was extended by 20 years (Table 4).

\section{Proportions of Stands Assigned to the Prescriptions}

The two scenarios that included the current range of rotation ages (Scenarios $1 \mathrm{a}$ and 2a) showed clear similarities in the proportions of stands that were assigned to various prescriptions (Figure 3). In these scenarios, 70\% of the total stands were assigned to Prescription 8 (no operations), while less than $4 \%$ of the total stands were assigned to Prescriptions 1 and 2 (rotation ages of 60 and 70 , respectively). The other two scenarios - both of which included a 20-year extension of the range of rotation ages (Scenarios $1 \mathrm{~b}$ and 2b) - also showed similarities in terms of the proportion of stands that were assigned to specific prescriptions. In these scenarios, $37 \%$ of the total stands were assigned to prescriptions with extended rotation ages (i.e., Prescriptions 6 and 7), while far less stands (less than half the proportion observed in the first two scenarios) were assigned to Prescription 8.

Table 4. Comparison of average annual total log harvest and woody biomass resources between scenarios including different ranges of rotation ages.

\begin{tabular}{ccccc}
\hline & $\begin{array}{c}\text { Harvest of total logs } \\
\left(\mathrm{m}^{3} \cdot \text { year }^{-1}\right)\end{array}$ & $\begin{array}{c}\text { Harvest of small-diameter logs } \\
\left(\mathrm{t} \cdot \mathrm{year}^{-1}\right)\end{array}$ & $\begin{array}{c}\text { Harvest of butt logs } \\
\left(\mathrm{t} \cdot \mathrm{year^{-1 } )}\right.\end{array}$ & $\begin{array}{c}\text { Sawing residues } \\
\left(\mathrm{t} \cdot \mathrm{year}^{-1}\right)\end{array}$ \\
\hline Scenario 1a & 22,989 & 1,464 & 2,686 & 1,930 \\
Scenario 1b & 47,783 & 2,736 & 5,463 & 4,067 \\
Ratio & 2.08 & 1.87 & 2.03 & 2.11 \\
\hline Scenario 2a & 22,921 & 1,514 & 2,751 & 1,907 \\
Scenario 2b & 53,552 & 3,187 & 6,229 & 4,528 \\
Ratio & 2.34 & 2.10 & 2.26 & 2.37 \\
\hline
\end{tabular}


Periodic Harvest and Production of Woody Biomass Resources

There were little difference in the various studied harvest volumes (total volume, butt logs, and small-diameter logs) between the tested scenarios that applied the current range of rotation ages (Scenarios 1a and 2a) (Figure 4). In contrast, large differences arose when the tested scenarios included an extended range of rotation lengths (Scenarios $1 b$ and $2 b$ ). Scenario $2 \mathrm{~b}$ showed greater periodic harvested volumes (total volume, butt logs, and small-diameter logs) than Scenario $2 \mathrm{a}$ in all the time periods except planning period 1 (Figure 5). The proportion of woody biomass resources in
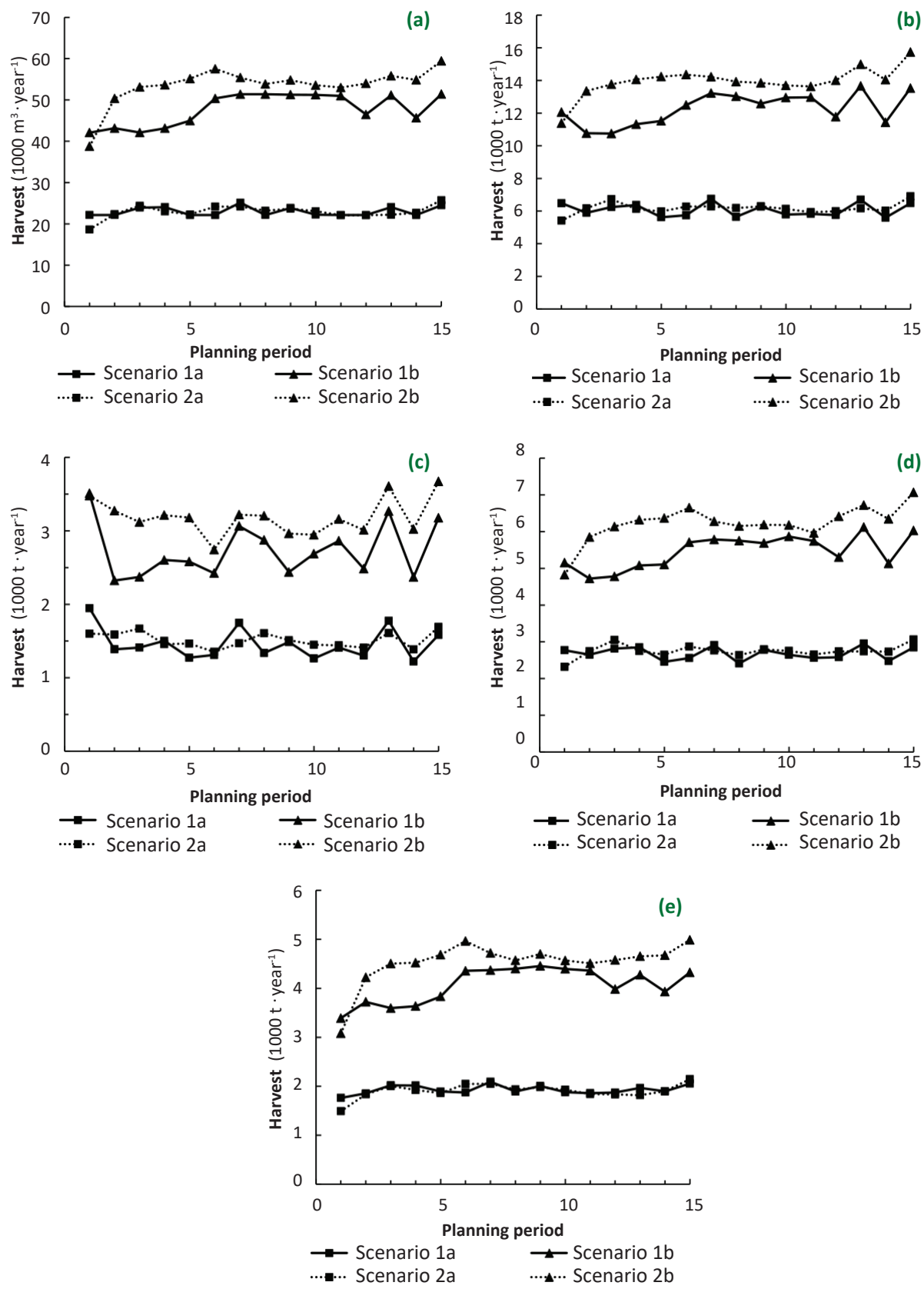

Figure 4. Changes in the periodic production of (a) total logs, (b) woody biomass resources, (c) small-diameter logs, (d) butt logs, and (e) sawing residues. 
Table 5. Fluctuation of woody biomass resources over the planning horizon.

\begin{tabular}{cccccc}
\hline Scenario & $\begin{array}{c}\text { Harvest of } \\
\text { small-diameter logs }\end{array}$ & $\begin{array}{c}\text { Harvest of } \\
\text { butt logs }\end{array}$ & $\begin{array}{c}\text { Harvest of } \\
\text { C-grade logs }\end{array}$ & $\begin{array}{c}\text { Sawing } \\
\text { residues }\end{array}$ & $\begin{array}{c}\text { Total woody biomass } \\
\text { resources }\end{array}$ \\
\hline $1 \mathrm{a}$ & 0.228 & 0.101 & 0.122 & 0.085 & 0.094 \\
$1 \mathrm{~b}$ & 0.203 & 0.129 & 0.143 & 0.136 & 0.119 \\
$2 \mathrm{a}$ & 0.112 & 0.138 & 0.096 & 0.180 & 0.121 \\
$2 \mathrm{~b}$ & 0.145 & 0.189 & 0.128 & 0.237 & 0.160 \\
\hline
\end{tabular}

Table 6. Fluctuation of woody biomass resources over the planning horizon (with planning period 1 eliminated).

\begin{tabular}{cccccc}
\hline Scenario & $\begin{array}{c}\text { Harvest of } \\
\text { small-diameter logs }\end{array}$ & $\begin{array}{c}\text { Harvest of } \\
\text { butt logs }\end{array}$ & $\begin{array}{c}\text { Harvest of } \\
\text { C-grade logs }\end{array}$ & $\begin{array}{c}\text { Sawing } \\
\text { residues }\end{array}$ & $\begin{array}{c}\text { Total woody biomass } \\
\text { resources }\end{array}$ \\
\hline $1 \mathrm{a}$ & 0.184 & 0.101 & 0.122 & 0.060 & 0.094 \\
$1 \mathrm{~b}$ & 0.169 & 0.129 & 0.143 & 0.107 & 0.119 \\
$2 \mathrm{a}$ & 0.112 & 0.075 & 0.075 & 0.082 & 0.075 \\
$2 \mathrm{~b}$ & 0.145 & 0.094 & 0.082 & 0.083 & 0.082 \\
\hline
\end{tabular}

the total harvest volume was at its maximum during planning period 1 (35\%-36\%), after which it decreased to 30\%-34\%. The proportion of small-diameter logs in woody biomass resources varied between $19 \%-26 \%$ in the periods other than planning period 1 , which showed a maximum proportion of $29 \%-30 \%$. The proportion of butt logs in woody biomass resources varied between $42 \%-46 \%$. The proportion of sawing residues in woody biomass resources was lowest in planning period $1(27 \%-28 \%)$, while this proportion ranged from $29 \%-36 \%$ during the other periods.

Fluctuations in total woody biomass resources were mostly less than $20 \%$, with the exception of the harvested volume of small-diameter logs in Scenarios $1 \mathrm{a}$ and $1 \mathrm{~b}$ (Table 5). However, if planning period 1 - which showed large fluctuation - is eliminated, all of the other observed fluctuations remained under $20 \%$, with most under $15 \%$ (Table 6). Scenarios $1 \mathrm{a}$ and $2 \mathrm{a}$ showed less fluctuation than Scenarios $1 b$ and $2 b$.

\section{DISCUSSION}

This paper showed the harvest of woody biomass resources over 150 years in a snowy mountainous region in Japan under the constraint of sustainable timber production. The developed model, which included a deviation threshold of $10 \%$, demonstrated that the harvested timber volumes fluctuated by $15 \%$ over the simulation period, which can be considered to represent a sustainable supply. Sacchelli et al. (2013) described forest energy supply chains using a model that included several parameters, and classified the biomass potential of the studied supply chains as either ecological, technical, economic, or sustainable. In this study, the maximal supply potential of woody biomass was estimated in the context of sustainability.

Aruga et al. (2014) only considered a rotation age of 60 years, which was used to calculate revenues and costs and then describe profitable stands. Kinoshita et al. (2010) earlier highlighted that extending the rotation age from
40 to 80 years could increase the biomass chip supply in Japan because it increases the profitability of plantation management. This study included a wide range of rotation ages, and certain scenarios extended the current maximal rotation age by a further 20 years. Expanding the range of rotation ages by 20 years dramatically increased the harvested volumes of various woody biomass resources, as well as the proportion of stands that would be harvested, and reduced the proportion of stands classified as Prescription 8. Stands were assigned to Prescription 8 when the profit over a rotation period was negative, or when the stand could not be harvested during the rotation period because of a constraint to stable harvests. The changes from a 20-year expansion can be explained by two reasons (Moriya and Tatsuhara 2014). First, a longer rotation age would lead to an increase in the harvested volume of large logs, which have an advantage in price when compared to smaller-diameter logs. Hence, an expansion of the rotation age would improve the profitability of plantations. The second reason - which is based on the unimodal age class distribution of trees (Figure 1 ) - is that some stands could not be harvested in order to stay within the $10 \%$ threshold for deviation between periods. An expansion in rotation age would decrease the proportion of such stands. The two reasons showed that revenues from harvest increased by expanding the range of rotation ages and ecological potential of woody biomass resources in the study site were much larger that the estimates in this study. The second reason showed that economical potential of woody biomass resources in the study site were also larger that the estimates in this study.

Extending the range of rotation ages also increased fluctuation in all of the tested types of woody biomass resources. The total harvested volume during each planning period was constrained to a $10 \%$ threshold for deviation by the harvest scheduling model. The variation observed for the harvested volumes of each grade and size of logs was higher than what was observed for the total harvested volume. Furthermore, changes in the objective functions did not noticeably affect the fluctuation of woody biomass 

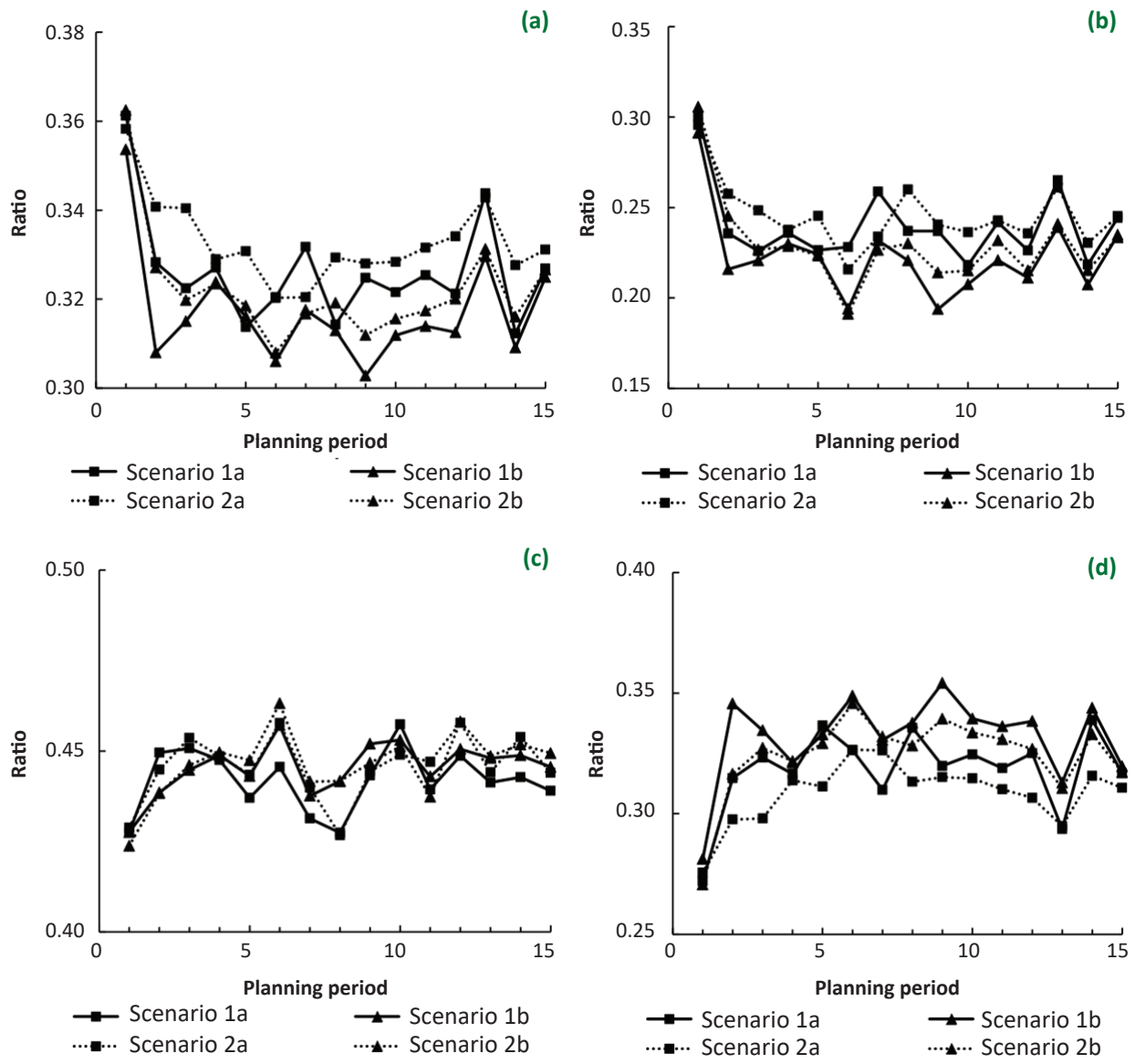

Figure 5. Changes in ratios of (a) periodic production of total woody biomass resources to periodic harvest of total logs, along with changes in the ratios of (b) periodic production of small-diameter logs, (c) periodic production of butt logs, (d) periodic production of sawing residues to periodic production of total woody biomass resources.

resources. However, Scenario $2 \mathrm{~b}$ produced more woody biomass resources than Scenario $1 \mathrm{~b}$, with the exception of planning period 1 , because of the increased harvesting of wood. This difference could be explained by an increase in the area of profitable stands in the current age class 6 (which represents the peak of the current age class distribution) after planning period 2 . This dramatically increased the area of harvestable stands, and also explained the instability in production of woody biomass resources noticed in planning period 1.

The generation of electricity by woody biomasspowered stations in the snowy regions of Japan has led to changes in the bucking strategy and increased the merchantable volume ratio. In terms of volume, butt logs comprise two-thirds of C-grade logs. These logs were previously not utilized whenever the butt log was bent due to a tree being bent by snowfall, but can now be used to produce fuel wood chips. Even though the price of woody biomass fuel chips is low compared to the price of regular roundwood, and only provides small additional income, this fraction nevertheless plays an important role in making sugi plantation management profitable (Suzuki and Tatsuhara (2016). Butt logs and small-diameter logs are cut to produce fuel chips, while sawing residues can either be used to produce fuel chips for woody biomass-powered generation facilities and boilers that dry lumber inside large sawmills, or material for mushroom cultivation beds. The estimated potential sustainable supply of biomass indicated that the $\mathrm{C}$-grade logs and part of the sawing residues would be used to generate electricity at biomass-powered stations.

Trømborg and Solberg (2010) showed that an increase in energy price will reduce the production of particleboard and pulp in Norway. The change in the bucking strategy at the study site (i.e., bent butt logs are cut to produce fuel chips) could be expected to reduce the supply of logs for sawn wood, laminated wood, and plywood. Regarding 
sawing residues, fuel chips for woody biomass-powered stations compete with material for mushroom cultivation beds. Thus, this competition should be modelled based on real-world prices, or, as an alternative, future predictions of potential biomass supply should establish which proportion of sawing residues will be used to produce fuel chips for woody biomass-powered generation facilities.

\section{CONCLUSIONS}

The presented model estimated the potential supply of woody biomass from plantation forests in a snowy district in Japan under a constraint of maximum sustainable harvest. The simulation showed that even though the age class distribution of trees was unimodal, the sustainable harvest of timber led to a sustainable supply of woody biomass over various rotation ages. Furthermore, extending the range of rotation ages by 20 years dramatically increased the potential supply of woody biomass resources. The methodology presented in this paper could be useful to individuals or organizations that are planning new woody biomass-powered facilities for energy generation and/or purchase biomass fuel chips. The presented research is also relevant to regional forest resource managers who mediate arranged transactions of logs between log producers and biomass purchasers. The potential supply estimated in this paper can be considered to represent the actual maximum supply for the study site because the value is based on maximum sustainable harvesting and assumes that all of the sawing residues will be used to produce fuel chips, which may not hold in the actual market for sawing residues. Most of the plantation forests in the study site were covered by 'forest management plans'. Other estimates of the potential supply of fuel chips for biomass-powered generation facilities should take into account which stands are included in 'forest management plans', as this is a prerequisite for obtaining higher tariffs from the current FIT scheme.

\section{Funding}

This study was funded by the Japan Society for the Promotion of Science (JSPS) Grants-in-Aid for Scientific Research (C) grant no. JP15K07469.

\section{Acknowledgments}

I would like to thank Mr. Takuya Iketani for calculating harvest volumes and fluctuations in woody biomass resources presented in his graduation thesis, and Ms. Naomi Sawada for providing the results of an interview with the biomass-powered generation facility in Niigata City. I would further like to thank the Division of Erosion Control, Department of Agriculture, Forestry, and Fishery, Niigata Prefectural Government for providing GIS data related to the forest inventory, along with maps and information on subsidies for private forests and the Niigata timber market. Lastly, I am grateful for the help of Niigata Prefecture Forest Owners' Co-operative Association in providing timber price records.

\section{Conflicts of Interest}

The author declares no conflict of interest.

\section{REFERENCES}

Ando N, 2013. Trends in woody biomass power generation and correspondence to its problems. Mon Rev Agric Forest Fish Financ 66(10): 24-39. (in Japanese).

Aruga K, Murakami A, Nakahata C, Yamaguchi R, Saito M, Yoshioka T, 2014. Estimating annual available amounts of forest biomass resources with total revenues and costs during the 60 -year rotation in a mountainous region in Japan. Croat $J$ For Eng 35(2): 125-128.

Aruga K, Yoshioka T, Sakurai R, 2006. Long-term feasibility of timber and forest biomass resources at an intermediate and mountainous area - balance of harvesting volumes using random search. J Jpn For Eng Soc 21(1): 49-59. https://doi. org/10.18945/jijes.KJ00007485443. (in Japanese with English summary).

Forestry Agency of Japan, 1981. Stand Density Control Diagram for Sugi in the Sea of Japan Coastal Tohoku and Hokuriku Regions. Japan Forest Technology Association, Tokyo, Japan. (in Japanese).

Geospatial Informatiom Authority of Japan, 2012. Download Service of Fundamental Geospatial Data. Available online: http://fgd.gsi.go.jp/download/ (15 July 2012).

Greenberg H, 1971. Integer Programming. Academic Press, New York, USA, $196 \mathrm{p}$.

Kinoshita T, Ohki T, Yamagata Y, 2010. Woody biomass supply potential for thermal power plants in Japan. Appl Energ 87(9): 2923-2927. https://doi.org/10.1016/i.apenergy.2009.08.025.
Moriya T, Tatsuhara S, 2014. Predicting of sustainable timber supply level considering stability of profits. J Jpn For Soc 96(2): 109-116. https://doi.org/10.4005/ijfs.96.109. (in Japanese with English summary).

Moriya T, Tatsuhara S, 2017. Effects of harvest restraint periods and fluctuation tolerances of profits and harvests on sustainable timber supply levels from private forests in a district. Forest Sci Technol 13(1): 17-24. https://doi.org/10.10 80/21580103.2016.1274274.

Nagumo H, Shiraishi N, Tanaka M, 1981. Computer programming for the construction of a sugi local yield-table - program TUSYCS. In: Nishizawa M (ed) Proceedings of Forest Resource Inventory, Growth Models, Management Planning and Remote Sensing, XVII IUFRO World Congress. Kyoto, Japan, pp 103-114.

NEDO, 2014. Renewable Energy Technology White Paper. $2^{\text {nd }}$ edn. Morikita Publishing, Tokyo, Japan, 672 p. (in Japanese).

Nelson J, Brodie JD, Sessions J, 1991. Integrating short-term, area-based logging plans with long-term harvest schedules. Forest Sci 37(1): 101-122. https://doi.org/10.1093/ forestscience/37.1.101.

Niigata Prefectural Government, 1980. Yield Tables for Niigata Prefecture. Niigata Prefectural Government, Niigata, Japan, 172 p. (in Japanese).

Nord-Larsen T, Talbot B, 2004. Assessment of forest-fuel resources in Denmark: technical and economic availability. Biomass Bioenerg 27(2): 97-109. https://doi.org/10.1016/j. biombioe.2004.01.007. 
Prodan M, 1965. Holzmesslehre. J. D. Sauerländer's Verlag, Frankfurt, Germany, 644 p.

Ranta T, 2005. Logging residues from regeneration fellings for biofuel production - a GIS-based availability analysis in Finland. Biomass Bioenerg 28(2): 171-182. https://doi. org/10.1016/j.biombioe.2004.08.010.

Rørstad Pk, Trømborg E, Bergseng E, Solberg B, 2010. Combining GIS and forest modelling in estimating regional supply of harvest residues in Norway. Silva Fenn 44(3): 435-451. https:// doi.org/10.14214/sf.141.

Sacchelli S, Fagarazzi C, Bernetti I, 2013. Economic evaluation of forest biomass production in central Italy: a scenario assessment based on spatial tool. Biomass Bioenerg 53: 1-19. https://doi.org/10.1016/i.biombioe.2012.11.026.

Suzuki K, Tatsuhara S, 2016. Effects of cross-cutting strategies and management conditions on profits from sugi (Cryptomeria japonica) plantations: Case studies of private forests in Sampoku District, Murakami City, Niigata Prefecture. Jpn J For Plann 50: 27-40. https://doi.org/10.20659/jifp.50.1 27. (in Japanese with English summary).

Suzuki K, Tatsuhara S, Nakajima T, Kanomata H, Oka M, 2018. Predicting effects of logging systems and bucking strategies for privately owned sugi (Cryptomeria japonica) plantations in Atsumi District, Tsuruoka City, Yamagata Prefecture. J For Plann 24: 15-27. https://doi.org/10.20659/ifp.24.215.
Takahashi T, Tatsuhara S, Zheng Y, Nagumo H, 1996. Economic evaluation of area-based forest plans: A case study for Tokyo University Forest in Chiba Prefecture. J For Plann 2: 5-11. https://doi.org/10.20659/ifp.2.15.

Tatsuhara S, Dobashi T, 2006. Classifying plantation forests in a snowy region according to cutting age using GIS: A case study of private forests in Sanpoku Town, Niigata Prefecture. J For Plann 12(1): 11-22. https://doi.org/10.20659/jfp.12.1 11.

Toyama K, Kamimura K, Yamasaki K, Tatsuhara S, 2009. Effect of terrain and geographical condition on operational efficiency in silvicultural operations. FORMATH 8: 13-23. (in Japanese with English summary).

Trømborg E, Solberg B, 2010. Forest sector impacts of the increased use of wood in energy production in Norway. Forest Policy Econ 12(1): 39-47. https://doi.org/10.1016/j. forpol.2009.09.011.

Yamaguchi R, Aruga K, Nagasaki M, 2014. Estimating the annual supply potential and availability of timber and logging residue using forest management records of the Tochigi prefecture, Japan. J For Res 19(1): 22-33. https://doi.org/10.1007/s10310013-0394-1. 